\title{
Brazilian multicentre study of common mental disorders in primary care: rates and related social and demographic factors
}

\section{Estudo multicêntrico brasileiro sobre transtornos mentais comuns na atenção primária: prevalência e fatores sociodemográficos relacionados}

\author{
Estudio brasileño multicéntrico de trastornos \\ mentales comunes en atención primaria: \\ prevalencia y factores sociodemográficos \\ relacionados
}

\author{
Daniel Almeida Gonçalves 1 \\ Jair de Jesus Mari 1 \\ Peter Bower 2 \\ Linda Gask 2 \\ Christopher Dowrick 3 \\ Luis Fernando Tófoli 4 \\ Monica Campos 5 \\ Flávia Batista Portugal 5 \\ Dinarte Ballester 6 \\ Sandra Fortes 7
}

\author{
1 Escola Paulista de \\ Medicina, Universidade \\ Federal de São Paulo, São \\ Paulo, Brasil. \\ 2 Manchester Academic \\ Health Science Centre, \\ University of Manchester, \\ Manchester, U.K. \\ 3 Institute of Psychology, \\ Health and Society, \\ University of Liverpool, \\ Liverpool, U.K. \\ 4 Faculdade de Ciências \\ Médicas, Universidade \\ Estadual de Campinas, \\ Campinas, Brasil. \\ ${ }^{5}$ Escola Nacional de Saúde \\ Pública Sergio Arouca, \\ Fundação Oswaldo Cruz, \\ Rio de Janeiro, Brasil. \\ 6 Programa de Pós-graduação \\ em Saúde Coletiva, \\ Universidade do Vale do Rio \\ dos Sinos, São Leopoldo, \\ Brasil. \\ 7 Faculdade de Ciências \\ Médicas, Universidade do \\ Estado do Rio de Janeiro, \\ Rio de Janeiro, Brasil. \\ Correspondence \\ D. A. Gonçalves \\ Departamento de Medicina \\ Preventiva, Escola Paulista \\ de Medicina, Universidade \\ Federal de São Paulo. \\ Rua Botucatu 740, 4o andar, \\ São Paulo, SP \\ 04023-062, Brasil. \\ daniel.almeida.33@gmail.com
}

\begin{abstract}
Mental health problems are common in primary health care, particularly anxiety and depression. This study aims to estimate the prevalence of common mental disorders and their associations with socio-demographic characteristics in primary care in Brazil (Family Health Strategy). It involved a multicenter cross-sectional study with patients from Rio de Janeiro, São Paulo Fortaleza (Ceará State) and Porto Alegre (Rio Grande do Sul State), assessed using the General Health Questionnaire (GHQ-12) and the Hospital Anxiety and Depression Scale (HAD). The rate of mental disorders in patients from Rio de Janeiro, São Paulo, Fortaleza and Porto Alegre were found to be, respectively, 51.9\%, 53.3\%, $64.3 \%$ and $57.7 \%$ with significant differences between Porto Alegre and Fortaleza compared to Rio de Janeiro after adjusting for confounders. Prevalence proportions of mental problems were especially common for females, the unemployed, those with less education and those with lower incomes. In the context of the Brazilian government's moves towards developing primary health care and reorganizing mental health policies it is relevant to consider common mental disorders as a priority alongside other chronic health conditions.
\end{abstract}

Mental Disorders; Mental Health; Primary Health Care

\section{Resumo}

Problemas de saúde mental são comuns na atenção primária e são geralmente relacionados à ansiedade e à depressão. Este estudo tem o objetivo de avaliar a taxa de transtornos mentais comuns e suas associações com características sociodemográficas em unidades de saúde da família. É um estudo multicêntrico, transversal, com os usuários da atenção primária do Rio de Janeiro, São Paulo, Fortaleza (Ceará) e Porto Alegre (Rio Grande do Sul), Brasil. Utilizou-se $o$ General Health Questionnaire (GHQ-12) e o Hospital Anxiety and Depression Scale (HAD). A taxa de transtornos mentais nos usuários do Rio de Janeiro, São Paulo, Fortaleza e Porto Alegre foram, respectivamente, 51,9\%, 53,3\%, 64,3\% e $57,7 \%$, com diferenças significativas entre Porto Alegre e Fortaleza comparando-se ao Rio de Janeiro. Problemas de saúde mental foram especialmente altos em mulheres, desempregados, em pessoas com baixa escolaridade e com baixa renda. Dadas as iniciativas do governo brasileiro para o desenvolvimento os cuidados primários e para reorganização da política pública de saúde mental, é importante considerar os transtornos mentais comuns como uma prioridade tal como outras morbidades crônicas.

Transtornos Mentais; Saúde Mental; Atenção Primária à Saúde 


\section{Introduction}

Common mental disorders are associated with disability $1,2,3$, poor prognosis of comorbid diseases 4,5 and impacts on health care costs and economic productivity 6,7,8. A significant proportion of the global health burden is attributable to mental health 9 . Severe mental health problems account for $21.5 \%$ of all disability-adjusted life years (DALYs) in Brazil 10,11. Recent epidemiological research among adults in the megacity of São Paulo showed a one-year prevalence of $19.9 \%$ for anxiety disorders, $11 \%$ for mood disorders, $4.3 \%$ for impulse-control disorders and $3.6 \%$ for substance abuse. These represented some of the highest prevalence estimates among cities around the world 12 .

In order to improve health conditions, the Brazilian government has been promoting significant changes in the health system, investing and remodelling primary care and mental health services ${ }^{13}$. It is proposed that the substantial burden of mental disorders can be reduced by integrating mental health into primary care, particularly in places with high levels of inequality and socioeconomic deprivation 14 . The Family Health Strategy (FHS) is the cornerstone of this integration, involving the introduction of 30,000 family health teams covering $95 \%$ of Brazil's municipalities and more than $50 \%$ of the population. Each team comprises one doctor and one nurse, two nurse assistants and six community health workers (in some teams there is also a dentist).

There are few studies of prevalence estimates of mental disorders in family health units in Brazil, and most of these were done in cities with no more than 650,000 people $15,16,17$. Some studies have taken place in large cities, but in traditional primary health centers 15,18,19,20,21. In Petrópolis (Rio de Janeiro State) ${ }^{22}$ and Santa Cruz do Sul (Rio Grande do Sul State) 16 a range of between 51 and 56 common mental disorders were found among people in family health units. Azevedo-Marques \& Zuardi 17 found $36.7 \%$ of any DSM-IV disorders (mainly mood and anxiety) in family health units in Ribeirão Preto (São Paulo State). Considering São Paulo or other big cities, the prevalence of psychiatric morbidity among patients in traditional primary health centers varies from $46 \%$ and $47 \%$ in São Paulo and Rio de Janeiro 15,19 to $56 \%$ in Porto Alegre 18.

Considering the breadth of responsibilities of the FHS - which include a major role in mental health - it is important to investigate further the epidemiology of common mental disorders in the context of the FHS in Brazil.

The aims of the current paper are: (i) to estimate the prevalence proportions of common mental disorders among patients in the FHS in four cities: São Paulo, Rio de Janeiro, Porto Alegre and Fortaleza; (ii) to study the association between sociodemographic factors and common mental disorders.

\section{Methods}

\section{Research design and population}

The study was based on surveys conducted during 2009 and 2010 in four state capitals (Rio de Janeiro, São Paulo, Fortaleza and Porto Alegre), which represent different regions of Brazil with considerable geographic and cultural differences. Porto Alegre is located in the Southern region of Brazil and has a population composed mainly of descendants of European immigrants, with an economy based on agro-industrial activities and one of the best Human Development Indices (HDI) in the country. Fortaleza is the 5th most populous city in Brazil, located in the Northeast region, with a high prevalence of illiteracy and a lower HDI. Its economy is based on business, commerce and tourism and its population is composed mainly of Portuguese and Native American descendants. São Paulo and Rio de Janeiro are located in the Southeast, the most industrialized, urbanized and wealthiest region of the country. São Paulo is the biggest city in South America and has a population based mainly on immigrants from Europe and Asia and migrants from the Northeast region of Brazil. Rio de Janeiro is the second largest city in the country. Its population is originally European and Afro-Brazilian with a strong presence of Northeastern migrants.

The study was originally designed to evaluate an intervention for training primary care and mental health workers in shared care ("apoio matricial" - matrix support), which is published elsewhere 23 . The population of interest was composed of patients from 20 urban health family primary care centers (family health units) with 27 family health teams from these four cities. These units were those chosen by the Health Secretaries from the four cities where training in mental health in primary care was considered a priority. The number of teams evaluated in each city was proportional to the number of professionals trained in each one: there were 3 teams in Porto Alegre, 3 in Fortaleza, 6 in São Paulo and 12 in Rio. All patients aged 18 to 65, and attending nurses and doctors were invited to take part in the study. Pregnant women (that indicate specific mental health morbidity) and patients with impaired cognitive functioning were not in- 
cluded. The original study was conceived as two cross-sectional surveys in a quasi-experimental pre-post design. The first cross-sectional survey was carried out from September to November 2009 and the second survey from June to August 2010. No patient who participated in the first survey was allowed to participate in the second. For this study, the entire sample was gathered and analysed together. For local logistical reasons, there was no sample from Fortaleza in the second phase.

The research protocol was approved by the Ethics Research Committee of the São Paulo Federal University, Rio de Janeiro State University and all four municipalities allowed the research to take place in their primary care health centers.

\section{Measures}

A researcher - who was based in the waiting room - obtained written consent from patients and applied the Portuguese version of the General Health Questionnaire (GHQ-12), Hospital Anxiety and Depression Scale (HAD) and a sociodemographic questionnaire. These instruments were applied as interviews due to the high illiteracy prevalence proportions within this population $15,19,20$.

The GHQ-12 was used to identify "probable common mental disorders" among patients. This instrument has been validated against a semi structured psychiatric interview 24,25 and the Brazilian version at the cut-off point of $2 / 3$ has demonstrated a sensitivity of $91 \%$ and specificity of $71 \%$ for the presence of common mental disorders in a population with no more than four years of schooling 22,26. To evaluate "probable depression" and "probable anxiety", the HAD scale was used with a cut-off of $8 / 9$ as previously validated in Brazil 27. These scores are associated with mood and anxiety distress, which is related with functional impairment and higher risk of developing mental disorders 28 .

Common mental disorders were used to highlight the psychiatric morbidity on emotional distress, as described by Goldberg \& Huxley 29. It is different than probable depression and/or anxiety disorders analyzed by specific scales that were used to point out more severe cases and also to allow comparison between wider data among other studies.

Sociodemographic data included gender, age, self-reported ethnicity, marital status, education (assessed in terms of years of schooling), employment status, income and ethnicity. Continuous variables were coded into dichotomous values. We divided ethnicity, income and education variables as: white or non-white, income higher or lower than half the minimum monthly wage per person per family (US\$126), and more or less than four years education (including the $4^{\text {th }}$ year).

\section{Data analyses}

The scores from GHQ-12 and HAD were dichotomized and taken as the dependent variables. Patients scoring at least 3 points on the GHQ were considered cases of "probable common mental disorders" and with 9 or more points in HAD for both subscales were cases of "probable depression" and "probable anxiety".

We present descriptive statistics on the prevalence proportions of "probable common mental disorders", "probable depression" and "probable anxiety". The chi square $\left(\chi^{2}\right)$ test was used to determine differences in prevalence proportions between sites. We used logistic regression to examine variation between cities in prevalence proportions of common mental disorders while adjusting for gender, age, education level, ethnicity, employment, and marital status. Odds ratios (OR) with 95\% confidence intervals $(95 \% \mathrm{CI})$ were calculated to estimate the association between sociodemographic variables and the presence of common mental disorders, depression and anxiety. Statistical analyses were performed using the IBM SPSS version 19.0 (IBM Corp., Armonk, USA).

\section{Results}

A total of 1,857 patients completed the screening questionnaires during the period of the surveys, $1,260(67.8 \%)$ in the first phase and $597(32.2 \%)$ in the second. 909 (48.9\%) were from Rio de Janeiro, 557 (30.1\%) from São Paulo, 171 (9.2\%) from Fortaleza and 220 (11.8\%) from Porto Alegre. Only income and employment status were significantly different between the samples from the two phases (Table 1).

Patients were mainly women over 35 years in age with more than four years of education. The majority were married or living with a partner and self reported their ethnicity as nonwhite. About one-third of patients come from a deprived background with family income lower than half the minimum wage at the time. Table 2 depicts sociodemographic characteristics between health centre patients among cities.

The prevalence proportion of common mental disorders, anxiety and depression are presented in Table 3. There were no significant differences between patients in these cities for common mental disorders, depression and anxiety, with 
Table 1

Comparison of sociodemographic characteristics in the two surveys.

\begin{tabular}{|c|c|c|c|}
\hline Total sample & Pre $(\%)(n=1,260)$ & Post $(\%)(n=597)$ & $p$-value \\
\hline \multicolumn{4}{|l|}{ Gender } \\
\hline Female & 76.6 & 78.9 & 0.29 \\
\hline \multicolumn{4}{|l|}{ Age group (years) } \\
\hline$>35$ & 68.4 & 66.3 & 0.35 \\
\hline \multicolumn{4}{|l|}{ Education level (years) } \\
\hline$\geq 4$ & 66.9 & 68.5 & 0.52 \\
\hline \multicolumn{4}{|l|}{ Race } \\
\hline Non-white & 72.8 & 66.4 & 0.07 \\
\hline \multicolumn{4}{|l|}{ Marital status } \\
\hline Having a partner & 62.3 & 58.6 & 0.12 \\
\hline \multicolumn{4}{|l|}{ Employment status } \\
\hline Have a job & 74.0 & 81.9 & 0.01 \\
\hline \multicolumn{4}{|c|}{ Income per person (US\$) } \\
\hline$<126$ & 45.1 & 35.8 & 0.01 \\
\hline \multicolumn{4}{|l|}{ GHQ-12 } \\
\hline Positive & 55.6 & 51.2 & 0.08 \\
\hline
\end{tabular}

GHQ-12: General Health Questionnaire.

Table 2

Comparison of sociodemographic characteristics of patients in the health centers in the studied cities.

\begin{tabular}{|c|c|c|c|c|c|}
\hline \multirow{2}{*}{$\begin{array}{l}\text { Sociodemographic } \\
\text { characteristics }\end{array}$} & \multicolumn{5}{|c|}{ Health centers (\%) } \\
\hline & $\begin{array}{l}\text { Rio de Janeiro } \\
\qquad(\mathrm{n}=909)\end{array}$ & $\begin{array}{l}\text { São Paulo } \\
(n=557)\end{array}$ & $\begin{array}{l}\text { Fortaleza } \\
(n=171)\end{array}$ & $\begin{array}{l}\text { Porto Alegre } \\
\qquad(n=220)\end{array}$ & Total \\
\hline \multicolumn{6}{|l|}{ Gender } \\
\hline Male & 22.0 & 26.0 & 11.7 & 25.5 & 22.7 \\
\hline Female & 78.0 & 74.0 & 88.3 & 74.5 & 77.3 \\
\hline \multicolumn{6}{|l|}{ Age (years) } \\
\hline $18-55$ & 81.6 & 76.5 & 85.4 & 87.3 & 32.3 \\
\hline$\geq 56$ & 18.4 & 23.3 & 14.6 & 12.7 & 18.9 \\
\hline \multicolumn{6}{|l|}{ Race } \\
\hline Non-white & 79.0 & 62.7 & 77.2 & 52.3 & 70.8 \\
\hline White & 21.0 & 37.3 & 22.8 & 47.7 & 29.2 \\
\hline \multicolumn{6}{|l|}{ Marital status } \\
\hline Other & 38.0 & 35.7 & 47.4 & 41.4 & 38.9 \\
\hline Having a partner & 61.4 & 64.3 & 52.6 & 58.6 & 61.1 \\
\hline \multicolumn{6}{|c|}{ Education level (years) } \\
\hline$<4$ & 35.3 & 30.9 & 32.7 & 25.5 & 32.6 \\
\hline$>4$ & 64.7 & 69.1 & 67.3 & 74.5 & 67.4 \\
\hline \multicolumn{6}{|c|}{ Personal income (US\$) } \\
\hline$<126$ & 36.3 & 34.5 & 41.5 & 20.9 & 34.4 \\
\hline$>126$ & 63.7 & 65.5 & 58.5 & 79.1 & 65.6 \\
\hline \multicolumn{6}{|c|}{ Monthly family income (US\$) } \\
\hline$<450$ & 90.6 & 89.5 & 98.8 & 88.8 & 90.8 \\
\hline$>450$ & 9.4 & 10.5 & 1.2 & 11.2 & 9.2 \\
\hline
\end{tabular}


Prevalence proportion of common mental disorders, anxiety and depression in studied cities and comparison between cities.

\begin{tabular}{|c|c|c|c|c|}
\hline & $\begin{array}{l}\text { Rio de Janeiro } \\
\qquad(n=909)\end{array}$ & $\begin{array}{l}\text { São Paulo } \\
(n=557)\end{array}$ & $\begin{array}{l}\text { Fortaleza } \\
(n=171)\end{array}$ & $\begin{array}{l}\text { Porto Alegre } \\
\qquad(n=220)\end{array}$ \\
\hline & $\%(95 \% \mathrm{Cl})$ & $\%(95 \% \mathrm{Cl})$ & $\%(95 \% \mathrm{Cl})$ & $\%(95 \% \mathrm{Cl})$ \\
\hline Common mental disorders & $51.9(48.7-55.2)$ & $53.3(49.2-57.5)$ & $64.3(57.1-71.2)$ & $57.7(51.2-64.3)$ \\
\hline Anxiety & $35.4(32.3-38.5)$ & $39.5(35.4-43.6)$ & $43.0(35.2-50.2)$ & $37.7(31.3-44.2)$ \\
\hline Depression & $25.0(22.1-27.8)$ & $25.3(21.7-29.0)$ & $31.0(24.0-38.0)$ & $21.4(16.0-26.8)$ \\
\hline
\end{tabular}

95\% Cl: 95\% confidence interval.

two exceptions. Among Fortaleza's patients the prevalence proportion of common mental disorders was significantly higher than in Rio de Janeiro's ( $\mathrm{p}=0.015$; OR = 1.60; 95\%CI: 1.58-1.63) even when adjusting for gender, income, employment status, race, marital condition and education level ( $\mathrm{p}=0.02$; OR = 1.86; 95\%CI: 1.45-2.27). Patients in Porto Alegre also presented significantly more common mental disorders than those in Rio de Janeiro after controlling for these sociodemographic factors $(\mathrm{p}=0.03$; $\mathrm{OR}=1.51 ; 95 \% \mathrm{CI}$ : 1.10-1.92).

Table 4 shows the associations between common mental disorders, depression and anxiety cases and sociodemographic factors. The bivariate analysis revealed that common mental disorders and depression were statistically and positively associated with gender, educational level and income. There were minor changes after controlling for all sociodemographic factors. Employment status was no longer related to common mental disorders and depression and educational level no longer showed significant associations with depression after adjusting for confounders.

\section{Discussion}

This paper reports the first multicentre study in Brazil examining the prevalence proportion of common mental disorders in primary care attendees and its association with patient sociodemographic factors. We found high prevalence proportions of common mental disorders, anxiety and depression in all cities. Patients attending primary care in Fortaleza and Porto Alegre presented significantly more common mental disorders than in Rio de Janeiro even after adjustment for confounding variables. There were no significant differences between patients from the health centers of these cities when we ana- lysed depression and anxiety disorders separately. Psychiatric morbidity among primary care patients was higher for females, those unemployed, those with less education, and those with lower income. After adjusting for the joint effects of sociodemographic factors on common mental disorders and anxiety, only employment status failed to show a significant association with disorder prevalence proportions. There was no association of depression with education level after adjustment for other variables.

The prevalence of mental health problems in primary health care is high, especially common mental disorders in all low and middle income countries, with particularly high prevalence proportions in Brazil. In Chile 30 and Nicaragua 31 it is $53 \%$ and $47 \%$, respectively, similar to India $32,33,34$ that is $50 \%$. Even in European countries, there is a high prevalence of psychiatric morbidity. Depression is present in $37 \%$ of patients in the UK $35,32.7 \%$ in Portugal 35, 35\% in the Netherlands 35 and $34.4 \%$ in Spain and Bosnia 36,37. There are ICD-10-PC diagnoses in $49.7 \%$ of primary health care patients in Denmark ${ }^{38}$. It is clear that there is a high prevalence of common mental disorders in primary care regardless of the average levels of income.

The present study found the highest prevalence proportions of "probable anxiety" (37.6\%) which is consistent with a recent epidemiological study that found a community prevalence of $19.9 \%$ in São Paulo - the highest compared with 23 other countries studied in the same survey 12 . There are many reasons which might explain the high prevalence proportions of anxiety disorders in Brazil, such as widespread urban violence and adverse socioeconomic conditions. It is known that one of the main sources of mortality and morbidity in Brazil is violence ${ }^{39}$. Furthermore, pollution, high noise levels and lack of recreational areas in Brazilian cities might be related with anxiety levels. 
Joint effects analysis of sociodemographic factors and psychiatric morbidity.

\begin{tabular}{|c|c|c|c|c|c|c|}
\hline \multirow[t]{2}{*}{ Characteristics (\%) } & \multicolumn{2}{|c|}{$\begin{array}{c}\text { CMD (+ = 54\%) } \\
{[n=1,006]}\end{array}$} & \multicolumn{2}{|c|}{$\begin{array}{c}\text { Anxiety }(+=38 \%) \\
{[n=698]}\end{array}$} & \multicolumn{2}{|c|}{$\begin{array}{c}\text { Depression (+ }=25 \%) \\
{[n=468]}\end{array}$} \\
\hline & $\%$ & $\begin{array}{l}\text { Adjusted OR } \\
(95 \% \mathrm{Cl})\end{array}$ & $\%$ & $\begin{array}{l}\text { Adjusted OR } \\
(95 \% \mathrm{Cl})\end{array}$ & $\%$ & $\begin{array}{l}\text { Adjusted OR } \\
(95 \% \mathrm{Cl})\end{array}$ \\
\hline \multicolumn{7}{|l|}{ Gender } \\
\hline Female (84\%) & 84.1 & $2.0(1.6-2.6)$ & 83.8 & $1.7(1.3-2.2)$ & 86.1 & $1.9(1.4-2.6)$ \\
\hline Male (16\%) & 15.9 & 1.0 & 16.2 & 1.0 & 13.9 & 1.0 \\
\hline \multicolumn{7}{|l|}{ Age (years) } \\
\hline$\leq 35(33 \%)$ & 33.0 & $1.0(0.8-1.3)$ & 34.8 & $1,2(0,9-1.5)$ & 32.1 & $0.97(0.9-1,6)$ \\
\hline > 35 (67\%) & 67.0 & 1.0 & 65.2 & 1.0 & 67.9 & 1.0 \\
\hline \multicolumn{7}{|l|}{ Employment } \\
\hline No $(26 \%)$ & 25.7 & $1.0(0.8-1.3)$ & 25.5 & $1.2(0.9,1-1.5)$ & 28.4 & $1.1(0.8-1.5)$ \\
\hline Yes (74\%) & 74.3 & 1.0 & 74.5 & 1.0 & 71.6 & 1.0 \\
\hline \multicolumn{7}{|c|}{ Education level (years) } \\
\hline$<4(72 \%)$ & 71.1 & $1.3(1.0-1.6)$ & 69.6 & $1.3(1.0-1.5)$ & 72.2 & $1.2(0.9-1.6)$ \\
\hline$>4(28 \%)$ & 28.7 & 1.0 & 28.8 & 1.0 & 27.6 & 1.0 \\
\hline \multicolumn{7}{|l|}{ Income (US\$) } \\
\hline$<126(47 \%)$ & 46.9 & $1.6(1.3-2.0)$ & 46.3 & $1.3(1.1-1.7)$ & 47.4 & $1.3(1.0-1.7)$ \\
\hline$>126(53 \%)$ & 47.2 & 1.0 & 47.1 & 1.0 & 44.9 & 1.0 \\
\hline \multicolumn{7}{|l|}{ Having a partner } \\
\hline Yes (60\%) & 59.5 & $1.2(0.9-1.4)$ & 61.9 & $0.9(0.7-1.1)$ & 59.6 & $1.0(0.8-1.3)$ \\
\hline No (40\%) & 40.5 & 1.0 & 38.1 & 1.0 & 40.4 & 1.0 \\
\hline \multicolumn{7}{|l|}{ Race } \\
\hline White (29\%) & 28.5 & $1.0(0.8-1.2)$ & 28.9 & $1.0(0.8-1.2)$ & 24.8 & $1.3(1.0-1.7)$ \\
\hline Non-white (71\%) & 71.5 & 1.0 & 71.1 & 1.0 & 75.2 & 1.0 \\
\hline
\end{tabular}

OR: odds ratio; $95 \% \mathrm{Cl}$ : 95\% confidence interval.

In accordance with other studies 19,33,34,38 we found associations between prevalence proportions of disorders, indicators of poverty and female gender. However, this profile of association changes among countries. In India 32,33,34 a low income is most strongly associated with common mental disorders, which was not observed in Chile 30 . In the present study this was the second most relevant variable, while gender was the most important factor. In contrast, being female in Chile is strongly associated with common mental disorders $(\mathrm{OR}=3)$ while in India there is no association. Patel \& Kleinman 40 pointed out in a review of 11 community studies in six low and middle income countries that the most consistent factor is low levels of education. We also found low education to be an important factor. After adjustment, education was not associated with depression. This could reflect an inverse correlation with social disadvantage, education level and prevalence of common mental disorders. In Chile 41 social class and education demonstrated a reduced strength of association after adjustment in a community survey. Similar results were found in Brazil 42 where the relationship between education and common mental disorders was significant only when the income was not extremely low. Extreme poverty reduced the strength of this association, probably because both factors are related and used to happen together in low and middle income countries.

The sample size for the surveys was calculated in order to assess changes in recognition of common mental disorders over time and not for a prevalence study. The number of patients who refused to participate was not assessed and, therefore, could not be included in the analysis. Consequently it was not possible to estimate the true prevalence among all patients and the results cannot be rigorously extrapolated for the population of each city. However, this sample should be comparable to the primary practice routine of other urban areas in Brazil. It is not possible to generalise to smaller urban areas and 
rural populations, although $85 \%$ of the Brazilian population is estimated to live in urban areas. The samples were from two cross-sectional surveys conducted at different times but were considered homogeneous enough for pooled analysis.

The screening questionnaires measure psychiatric symptoms and do not provide a formal diagnosis. However, in practice, emotional distress is related with disability and poor social functioning 28 . Individuals with sub-threshold depression and anxiety are frequently seen in primary care 43 and some researchers suggest that these conditions are important contributors to overall impairment and high service utilization 44 . It is very important to measure and identify probable cases at risk of developing formal psychiatric disorders. It is justifiable to use the concept of common mental disorders, which encompasses emotional distress with vulnerability and recovery 29 , and does not exclusively focus on categorical classification such as depression and anxiety.

Discussing the possible implications of the results of this study to the delivery of care to the Brazilian population is one of the most important consequences of the results we have found. With over half of all adults attending primary care being classified as having probable common mental disorders, health policies must be developed to address this public health problem, which differ substantially to the patients usually attending specialized units that have been the emphasis of mental health planning in recent years in Brazil.

First of all, it is important not to see common mental disorders as only categorical diagnoses, but as possible risk factors for the development of more severe disorders 46 . Despite some possible biases about high common mental disorders prevalence proportions as over reporting or diagnosing self limited cases, family health teams must be aware of the extent of psychosocial problems in order to take an integrated care approach. Studies have demonstrated evidences of cost-effectiveness and efficacy of psychosocial interventions for common mental disorders in low and middle income countries 45 , but implementing these interventions and developing confidence and skills in primary care professionals is challenging. Training and education programs for primary care professions need to be introduced together with structured pathways and network support services 42 .

Education strategies must involve additional competencies other than simply diagnosing and managing medication in common mental health disorders 46 . The strong association of emotional distress with psychosocial variables suggest that psychosocial interventions may help in supporting these patients. Involving other primary care professionals (such as community health workers and nurse assistants) may help teams identify cases 17 . Supporting professionals should be available in order to help primary care professionals manage common mental disorders and more severe problems. Recent evidence demonstrated the effectiveness of primary care-specialist collaboration 47 . In Brazil, matrix support introduced this collaborative model, but the support of specialists must be made accessible to all primary care teams and shared care coordinated by appropriate management 48 .

Finally, policy-makers must make efforts to reduce economic inequities and implement educational and public safety policies to overcome the vicious circle of poverty, urban violence and mental disorders, acting directly for promoting human wellbeing.

\section{Conclusion}

This study reports high levels of probable mental health problems among four state capitals and identifies associations between sociodemographic characteristics and mental health problems in primary health care. Considering the moves the Brazilian government is making towards the development of primary care and the reform of its mental health policies, it is very relevant to consider common mental disorders as a priority alongside other chronic health conditions. Establishing comprehensive care at primary care level and integrating health services are relevant steps to achieving equity in the Brazilian national health system. 


\section{Resumen}

Los problemas de salud mental son comunes en la atención primaria y están relacionados con la ansiedad y la depresión. Este estudio tiene como objetivo evaluar las tasas de trastornos mentales comunes y sus asociaciones con las características sociodemográficas de los usuarios de la atención primaria. Se trata de un estudio multicéntrico, transversal, con usuarios de Río de Janeiro, São Paulo, Fortaleza y Porto Alegre, Brasil. Se utilizó el General Health Questionnaire (GHQ-12) y el Hospital Anxiety and Depression Scale (HAD). La tasa de trastornos mentales en pacientes de Río de Janeiro, São Paulo, Fortaleza (Ceará) y Porto Alegre (Río Grande do Sul) fueron, respectivamente, 51,9\%, 53,3\%, 64,3\% y 57,7\%, con diferencias significativas entre Porto Alegre y Fortaleza. Los problemas de salud mental fueron especialmente altos en las mujeres, desempleados, personas con bajo nivel educativo y quienes tienen bajos ingresos. Teniendo en cuenta los esfuerzos del gobierno brasileño para el desarrollo de la atención primaria y las políticas para la reorganización de la salud mental es importante considerar los trastornos mentales como una prioridad junto a otras afecciones crónicas.

Trastornos Mentales; Salud Mental; Atención Primaria de Salud

\section{Contributors}

D. A. Gonçalves contributed to the methodological design, statistical analysis and writing of the paper. J. J. Mari contributed to the methodological design and writing and revision of the paper. P. Bower, L. Gask and C. Dowrick contributed to the methodological design and writing of the paper. L. F. Tófoli contributed to the methodological design, data collection and writing of the paper. F. B. Portugal contributed to the data analysis and writing of the paper. D. Ballester contributed to the study design, data collection and revision of the paper. M. Campos contributed to the methodological and study design, data interpretation, statistical analysis and revision of the paper. S. Fortes contributed to the study design, data collection and revision of the paper.

\section{Acknowledgments}

To all the professionals from the Family Health Strategy and people from São Paulo, Rio de Janeiro, Fortaleza and Porto Alegre who provided their time and energy to participate in the study. To CNPq that funded the research and university and research staff who helped the development of the research.

\section{References}

1. Kessler RC, Aguilar-Gaxiola S, Alonso J, Chatterji S, Lee S, Ormel J, et al. The global burden of mental disorders: an update from the WHO World Mental Health (WMH) surveys. Epidemiol Psichiatr Soc 2009; 18:23-33.

2. Druss BG, Hwang I, Petukhova M, Sampson NA, Wang PS, Kessler RC. Impairment in role functioning in mental and chronic medical disorders in the United States: results from the National Comorbidity Survey Replication. Mol Psychiatry 2009; 14:728-37.

3. Eaton WW, Martins SS, Nestadt G, Bienvenu OJ, Clarke D, Alexandre P. The burden of mental disorders. Epidemiol Rev 2008; 30:1-14

4. Scott KM, Von Korff M, Alonso J, Angermeyer MC, Bromet E, Fayyad J, et al. Mental-physical co-morbidity and its relationship with disability: results from the World Mental Health Surveys. Psychol Med 2009; 39:33-43.

5. Patten SB, Williams JVA, Lavorato DH, Modgill G, Jette N, Eliasziw M. Major depression as a risk factor for chronic disease incidence: longitudinal analyses in a general population cohort. Gen Hosp Psychiatry 2008; 30:407-13.
6. Bijl D, van Marwijk HWJ, de Haan M, van Tilburg W, Beekman A-JTF. Effectiveness of disease management programmes for recognition, diagnosis and treatment of depression in primary care. Eur J Gen Pract 2004; 10:6-12.

7. Kohn R, Saxena S, Levav I, Saraceno B. The treatment gap in mental health care. Bull World Health Organ 2004; 82:858-66.

8. Prince M, Patel V, Saxena S, Maj M, Maselko J, Phillips MR, et al. No health without mental health. Lancet 2007; 370:859-77.

9. World Health Organization. Mental health gap action programme: scaling up care for mental, neurological, and substance use disorders. Geneva: World Health Organization; 2008.

10. World Health Organization. World health statistics 2010. Geneva: World Health Organization; 2010.

11. Schramm JA, Oliveira AF, Leite IC, Valente JG, Gadelha AJ, Portela MC, et al. Transição epidemiológica e o estudo de carga de doença no Brasil. Ciênc Saúde Coletiva 2004; 9:897-908. 
12. Andrade LH, Wang Y-P, Andreoni S, Silveira CM, Alexandrino-Silva C, Siu ER, et al. Mental disorders in megacities: findings from the São Paulo megacity mental health survey, Brazil. PLoS One 2012; 7:e31879.

13. Harris M, Haines A. Brazil's Family Health Programme. BMJ 2010; 341:c4945.

14. World Health Organization. Integrating mental health into primary health care a global perspective. Geneva: World Health Organization; 2008.

15. Üstürn TB, Sartorius N, Villano LB. Mental illness in general health care an international study. Chichester: Wiley \& Sons; 1995.

16. Gonçalves DM, Kapczinski F. Prevalência de transtornos mentais em indivíduos de uma unidade de referência para Programa Saúde da Família em Santa Cruz do Sul, Rio Grande do Sul, Brasil. Cad Saúde Pública 2008; 24:2043-53.

17. Azevedo-Marques JM, Zuardi AW. COOP/WONCA charts as a screen for mental disorders in primary care. Ann Fam Med 2011; 9:359-65.

18. Busnello ED, Lima BR, Bertolote JM. Aspectos interculturais de classificação e diagnóstico. J Bras Psiquiatr 1983; 32:207-10.

19. Mari JJ. Psychiatric morbidity in three primary medical care clinics in the city of Sao Paulo. Issues on the mental health of the urban poor. Soc Psychiatry 1987; 22:129-38.

20. Iacoponi E. The detection of emotional disorders by primary care physicians: a study in São Paulo, Brazil. London: Univestity of London; 1989.

21. Almeida MD, Nunes MA, Camey S, Pinheiro AP, Schmidt MI. Transtornos mentais em uma amostra de gestantes da rede de atenção básica de saúde no Sul do Brasil. Cad Saúde Pública 2012; 28:385-94

22. Fortes S, Villano LB, Lopes CS. Nosological profile and prevalence of common mental disorders of patients seen at the Family Health Program (FHP) units in Petropolis, Rio de Janeiro. Rev Bras Psiquiatr 2008; 30:32-7.

23. Gonçalves DA, Fortes S, Campos M, Ballester D, Portugal, FB, Tófoli LF, et al. Evaluation of a mental health training intervention for multidisciplinary teams in primary care in Brazil: a pre- and posttest study. Gen Hosp Psychiatry 2013; 35:304-8.

24. Goldberg D. Manual of the General Health Questionnaire. Windsor: National Foundation for Educational Research; 1978.

25. Mari JJ, Williams P. A comparison of the validity of two psychiatric screening questionnaires (GHQ12 and SRQ-20) in Brazil, using relative operating characteristic (ROC) analysis. Psychol Med 1985; 15:651-9.

26 Mari JJ, Iacoponi E, Williams P, Simões O, Silva JB. Detection of psychiatric morbidity in the primary medical care setting in Brazil. Rev Saúde Pública 1987; 21:501-7.

27. Botega NJ, Bio MR, Zomignani MA, Garcia Jr. C, Pereira WA. Transtornos do humor em enfermaria de clínica médica e validação de escala de medida (HAD) de ansiedade e depressão. Rev Saúde Pública 1995; 29:355-63.
28 Judd LL, Paulus MP, Wells KB, Rapaport MH. Socioeconomic burden of subsyndromal depressive symptoms and major depression in a sample of the general population. Am J Psychiatry 1996; 153:1411-7.

29. Goldberg DP, Huxley P. Common mental disorders a bio-social model. London: Tavistock/Routledge; 1992.

30. Araya R, Wynn R, Leonard R, Lewis G. Psychiatric morbidity in primary health care in Santiago, Chile: preliminary findings. Br J Psychiatry 1994; 165:530-3.

31. Penayo U, Kullgren G, Caldera T. Mental disorders among primary health care patients in Nicaragua. Acta Psychiatr Scand 1990; 82:82-5.

32 Patel V, Todd C, Winston M, Gwanzura F, Simunyu E, Acuda W, et al. Common mental disorders in primary care in Harare, Zimbabwe: associations and risk factors. Br J Psychiatry 1997; 171:60-4.

33 Patel V, Pereira J, Mann AH. Somatic and psychological models of common mental disorder in primary care in India. Psychol Med 1998; 28:135-43.

34. Pothen M, Kuruvilla A, Philip K, Joseph A, Jacob KS. Common mental disorders among primary care attenders in Vellore, South India: nature, prevalence and risk factors. Int J Soc Psychiatry 2003; 49:119-25.

35. King M, Nazareth I, Levy G, Walker C, Morris R, Weich S, et al. Prevalence of common mental disorders in general practice attendees across $\mathrm{Eu}-$ rope. Br J Psychiatry 2008; 192:362-7.

36. Roca M, Gili M, Garcia-Garcia M, Salva J, Vives M, Garcia-Campayo J, et al. Prevalence and comorbidity of common mental disorders in primary care. J Affect Disord 2009; 119:52-8.

37. Broers T, Hodgetts G, Batic-Mujanovic O, Petrovic V, Hasanagic M, Godwin M. Prevalence of mental and social disorders in adults attending primary care centers in Bosnia and Herzegovina. Croat Med J 2006; 47:478-84.

38. Toft T, Fink P, Oernboel E, Christensen K, Frostholm L, Olesen F. Mental disorders in primary care: prevalence and co-morbidity among disorders: results from the functional illness in primary care (FIP) study. Psychol Med 2005; 35:1175-8.

39. Reichenheim ME, Souza ER, Moraes CL, MelloJorge MHP, Silva CMFP, Minayo MCS. Violence and injuries in Brazil: the effect, progress made, and challenges ahead. Lancet 2011; 377:1962-75.

40. Patel V, Kleinman A. Poverty and common mental disorders in developing countries. Bull World Health Organ 2003; 81:609-15.

41. Araya R, Rojas G, Fritsch R, Acuna J, Lewis G. Common mental disorders in Santiago, Chile: prevalence and socio-demographic correlates. Br J Psychiatry 2001; 178:228-33.

42. Dowrick C. Advances in psychiatric treatment in primary care. Adv Psychiatric Treatment 2001; 7: 1-8.

43. Olfson M, Broadhead WE, Weissman MM, Leon AC, Farber L, Hoven C, et al. Subthreshold psychiatric symptoms in a primary care group practice. Arch Gen Psychiatry 1996; 53:880-6. 
44. Johnson J, Weissman MM, Klerman GL. Service utilization and social morbidity associated with depressive symptoms in the community. JAMA 1992; 267:1478-83.

45. Patel V, Araya R, Chatterjee S, Chisholm D, Cohen A, De Silva M, et al. Treatment and prevention of mental disorders in low-income and middle-income countries. Lancet 2007; 370:991-1005.

46. Fortes S, Lopes CS, Villano LAB, Campos MR, Goncalves DA, Mari JJ. Common mental disorders in Petropolis-RJ: a challenge to integrate mental health into primary care strategies. Rev Bras Psiquiatr 2011; 33:150-6.
47. Foy R, Hempel S, Rubenstein L, Suttorp M, Seelig M, Shanman R, et al. Meta-analysis: effect of interactive communication between collaborating primary care physicians and specialists. Ann Intern Med 2010; 152:247-58.

48. Kates N, McPherson-Doe C, George L. Integrating mental health services within primary care set tings: the Hamilton Family Health Team. J Ambu Care Manage 2008; 34:174-82.

Submitted on 29/Oct/2012

Final version resubmitted on 24/Jul/2013

Approved on 16/Sep/2013 